\title{
Bacillus neizhouensis sp. nov., a halophilic marine bacterium isolated from a sea anemone
}

\author{
Yi-Guang Chen, ${ }^{1,2}$ Yu-Qin Zhang, ${ }^{3}$ Yong-Xia Wang, ${ }^{2}$ Zhi-Xiong Liu, ${ }^{1}$ \\ Hans-Peter Klenk, ${ }^{4}$ Huai-Dong Xiao, ${ }^{1}$ Shu-Kun Tang, ${ }^{2}$ Xiao-Long Cui ${ }^{2}$ \\ and Wen-Jun $\mathrm{Li}^{2,5}$
}

Correspondence

Wen-Jun Li

wjli@ynu.edu.cn

Yi-Guang Chen

mchenjsu@yahoo.com.cn

\author{
${ }^{1}$ College of Biology and Environmental Sciences, College of Chemistry and Chemical Engineering, \\ Jishou University, Jishou 416000, PR China \\ ${ }^{2}$ The Key Laboratory for Microbial Resources of the Ministry of Education, PR China, and \\ Laboratory for Conservation and Utilization of Bio-Resources, Yunnan Institute of Microbiology, \\ Yunnan University, Kunming 650091, PR China \\ ${ }^{3}$ Institute of Medicinal Biotechnology, Chinese Academy of Medical Sciences \& Peking Union \\ Medical College, Beijing 100050, PR China \\ ${ }^{4}$ Deutsche Sammlung von Mikroorganismen und Zellkulturen, D-38124 Braunschweig, Germany \\ ${ }^{5}$ Guangdong Key Laboratory of Marine Materia Medica, South China Sea Institute of Oceanology, \\ Chinese Academy of Sciences, Guangzhou 510301, PR China
}

\begin{abstract}
A novel Gram-stain-positive, slightly halophilic, facultatively alkaliphilic, non-motile, catalase- and oxidase-positive, endospore-forming, rod-shaped, aerobic bacterium, strain JSM $071004^{\top}$, was isolated from a sea anemone collected from Neizhou Bay in the South China Sea. Growth occurred with $0.5-10 \%(\mathrm{w} / \mathrm{v})$ total salts (optimum 2-4\%) and at $\mathrm{pH} 6.5-10.0$ (optimum pH 8.5) and $4-30{ }^{\circ} \mathrm{C}$ (optimum $25^{\circ} \mathrm{C}$ ). meso-Diaminopimelic acid was present in the cell-wall peptidoglycan. The predominant respiratory quinone was menaquinone 7 (MK-7) and the polar lipids consisted of diphosphatidylglycerol, phosphatidylglycerol and phosphatidylethanolamine.

The major cellular fatty acids were anteiso- $C_{15: 0}$ and iso- $C_{15: 0}$. The genomic DNA $G+C$ content was $39.8 \mathrm{~mol} \%$. Phylogenetic analysis based on 16S rRNA gene sequences indicated that strain JSM $071004^{\top}$ belongs to the genus Bacillus, being related most closely to the type strain of Bacillus agaradhaerens (sequence similarity $97.3 \%$ ), followed by the type strains of Bacillus cellulosilyticus (96.2\%), Bacillus clarkii (96.1\%) and Bacillus polygoni (96.0\%). The combination of phylogenetic analysis, DNA-DNA hybridization, phenotypic characteristics and chemotaxonomic data support the proposal that strain JSM $071004^{\top}$ represents a novel species of the genus Bacillus, for which the name Bacillus neizhouensis sp. nov. is proposed, with JSM $071004^{\top}\left(=\right.$ CCTCC AB $207161^{\top}=$ DSM $19794^{\top}=$ KCTC $\left.13187^{\top}\right)$ as the type strain.
\end{abstract}

There has been increasing interest in halophilic, halotolerant, alkaliphilic and/or alkalitolerant Bacillus species, attributable to their ability to grow under extreme conditions as well as to the use of their enzymes in biotechnological applications (Ash et al., 1991; Nielsen et al., 1994, 1995; Horikoshi, 1999; Margesin \& Schinner, 2001; Arahal \& Ventosa, 2002; Yoon et al., 2004; Nogi et al., 2005; Romano et al., 2005; Lim et al., 2006a, b; Carrasco et al., 2007; Krulwich et al., 2007; Yumoto, 2007; Aino et al., 2008). During investigation of the diversity of the microbial population of invertebrates inhabiting the South China Sea (Chen et al., 2009a, b; Xiao et al.,

The GenBank/EMBL/DDBJ accession number for the $16 \mathrm{~S}$ rRNA gene sequence of strain JSM $071004^{\top}$ is EU925618.
2009), a slightly halophilic, facultatively alkaliphilic, endospore-forming, Gram-stain-positive bacterium, designated JSM $071004^{\mathrm{T}}$, was isolated from a sea anemone collected from the Neizhou Bay, China. Based on the results of a polyphasic taxonomic study, this strain is considered to represent a novel species of the genus Bacillus.

Strain JSM $071004^{\mathrm{T}}$ was isolated from homogenates of a sea anemone by plating $1: 10$ serial dilutions of the sample on marine agar 2216 (MA; Difco) cultivated at $25{ }^{\circ} \mathrm{C}$ for 2 weeks. After primary isolation and purification, the isolate was preserved both on MA slants at $4{ }^{\circ} \mathrm{C}$ and in marine broth 2216 (MB; Difco) supplemented with $20 \%$ $(\mathrm{v} / \mathrm{v})$ glycerol at $-80{ }^{\circ} \mathrm{C}$. Unless otherwise indicated, 
morphological and physiological studies were performed with cells grown on MA at $\mathrm{pH} 8.5$ and $25{ }^{\circ} \mathrm{C}$. Cell morphology was examined by light microscopy (model $\mathrm{BH} 2$; Olympus). Gram staining was carried out by using the standard Gram reaction combined with the $\mathrm{KOH}$ lysis method (Gregersen, 1978). Flagella and endospores were examined according to the methods of Leifson and Schaeffer-Fulton, respectively (Smibert \& Krieg, 1994). Growth was tested at various temperatures $(0,4$ and $5-45{ }^{\circ} \mathrm{C}$, in increments of $\left.5{ }^{\circ} \mathrm{C}\right)$ and at different $\mathrm{pH}(5.0$ 11.0 , in increments of $0.5 \mathrm{pH}$ units) on MA and in MB. For $\mathrm{pH}$ experiments, the buffer solutions described by Chen et al. (2007) were used. Growth at different total-salt concentrations $(0,0.1,0.5$ and $1-15 \%, \mathrm{w} / \mathrm{v}$, in increments of $1 \%$ ) was determined on MA prepared according to the formula of Atlas (1993). The concentration of all salts contained in MA was changed (keeping proportions the same) in the salt-response experiment. Methyl red and Voges-Proskauer tests, $\mathrm{H}_{2} \mathrm{~S}$ production from L-cysteine, hydrolysis of aesculin, indole production and nitrate and nitrite reduction were tested as recommended by Smibert \& Krieg (1994). Hydrolysis of casein, cellulose, DNA, gelatin, starch, Tweens 20,40, 60 and 80 and urea was determined as described by Cowan \& Steel (1965). Determination of acid production from carbohydrates, as well as utilization of carbon and nitrogen sources, was performed as recommended by Ventosa et al. (1982). Motility, growth under anaerobic conditions, antibiotic susceptibility and catalase and oxidase activities were detected as described previously (Chen et al., 2007). Other enzymic activities were tested by using API ZYM systems (bioMérieux) according to the manufacturer's instructions with $3 \%(\mathrm{w} / \mathrm{v}) \mathrm{NaCl}$.

Strain JSM $071004^{\mathrm{T}}$ was slightly halophilic and facultatively alkaliphilic, with optimum growth occurring at 2-4\% $(\mathrm{w} / \mathrm{v})$ total salts and at $\mathrm{pH} 8.5$. It was able to grow at 4$30{ }^{\circ} \mathrm{C}$, with optimum growth at $25{ }^{\circ} \mathrm{C}$. Colonies were paleyellow pigmented, low convex and translucent with circular/slightly irregular margins and 1-2 mm diameter after incubation for $3-5$ days at $25^{\circ} \mathrm{C}$ on $\mathrm{MA}(\mathrm{pH} 8.5)$. Cells were Gram-stain-positive, endospore-forming, catalase- and oxidase-positive, aerobic, straight rods. The results of other phenotypic tests are summarized in the species description and in Table 1.

Genomic DNA was isolated according to Hopwood et al. (1985) and the $\mathrm{G}+\mathrm{C}$ content was determined using the HPLC method (Mesbah et al., 1989). The 16S rRNA gene was amplified and sequenced as described previously (Cui et al., 2001). Pairwise sequence similarities were calculated using a global alignment algorithm, which was implemented at the EzTaxon server (Chun et al., 2007). Phylogenetic analysis was performed by using the software package MEGA version 4.1 (Tamura et al., 2007) after multiple alignment of sequence data by CLUSTAL_X (Thompson et al., 1997). Distances were calculated using distance options according to Kimura's two-parameter model (Kimura, 1980) and clustering was performed by the neighbour-joining method
Table 1. Characteristics used to distinguish strain JSM $071004^{\top}$ from the type strains of phylogenetically related Bacillus species

Strains: 1, Bacillus neizhouensis sp. nov. JSM $071004^{\mathrm{T}}$ (data from this study); 2, B. agaradhaerens DSM $8721^{\mathrm{T}}$ (Nielsen et al., 1995; Lim et al., 2006a, b); 3, B. cellulosilyticus $\mathrm{N}-4^{\mathrm{T}}$ (Nogi et al., 2005); 4, B. clarkii DSM $8720^{\mathrm{T}}$ (Nielsen et al., 1995; Lim et al., 2006a, b); 5, Bacillus polygoni $\mathrm{YN}-1^{\mathrm{T}}$ (Aino et al., 2008); 6, B. vedderi DSM $9768^{\mathrm{T}}$ (Nielsen et al., 1995; Nogi et al., 2005; Lim et al., 2006b); 7, B. saliphilus $6 \mathrm{AG}^{\mathrm{T}}$ (Romano et al., 2005); 8, B. chagannorensis CG- $15^{\mathrm{T}}$ (Carrasco et al., 2007). +, Positive; -, negative; ND, no data available.

\begin{tabular}{|lcccccccc|}
\hline Characteristic & $\mathbf{1}$ & $\mathbf{2}$ & $\mathbf{3}$ & $\mathbf{4}$ & $\mathbf{5}$ & $\mathbf{6}$ & $\mathbf{7}$ & $\mathbf{8}$ \\
\hline Oxidase & + & - & - & - & - & + & + & - \\
Facultatively & - & - & $\mathrm{ND}$ & - & - & + & $\mathrm{ND}$ & + \\
$\quad$ anaerobic & & & & & & & & \\
Motility & - & + & + & $\mathrm{ND}$ & - & + & - & + \\
Hydrolysis of: & & & & & & & & \\
$\quad$ Casein & - & + & - & + & + & - & - & - \\
Gelatin & + & - & - & + & - & + & + & - \\
Starch & - & + & + & - & - & - & - & - \\
Tween 20 & - & - & + & - & + & - & ND & ND \\
Tweens 40 & - & + & + & + & + & + & ND & ND \\
and 60 & & & & & & & & \\
Growth at: & & & & & & & & \\
$15 \%(w / v) ~ N a C l$ & - & + & - & + & - & - & + & + \\
$4{ }^{\circ} \mathrm{C}$ & + & - & - & - & - & - & - & - \\
$35{ }^{\circ} \mathrm{C}$ & - & + & + & + & + & + & + & + \\
pH 6.5 & + & - & - & - & - & - & - & + \\
pH 11 & - & + & - & + & + & - & - & + \\
DNA G+C & 39.8 & 39.5 & 39.6 & 42.4 & 42.9 & 38.3 & 48.4 & 53.8 \\
content $(\mathrm{mol} \%)$ & & & & & & & & \\
\hline
\end{tabular}

(Saitou \& Nei, 1987). Maximum-likelihood (Felsenstein, 1981) and parsimony (Kluge \& Farris, 1969) trees (not shown) were generated by using the treeing algorithms contained in the PHYLIP package (Felsenstein, 2002). Bootstrap analysis was used to evaluate the tree topology of the neighbour-joining data by means of 1000 resamplings (Felsenstein, 1985). DNA-DNA hybridization was carried out at $37^{\circ} \mathrm{C}$ by using photobiotin-labelled probes in microplate wells as described by Ezaki et al. (1989).

The DNA G + C content of strain JSM $071004^{\mathrm{T}}$ was $39.8 \mathrm{~mol} \%$. The almost-complete $16 \mathrm{~S}$ rRNA gene sequence (1479 bp) was determined. Phylogenetic analysis based on 16S rRNA gene sequences revealed that strain JSM $071004^{\mathrm{T}}$ belongs to the genus Bacillus, being related most closely to the type strain of Bacillus agaradhaerens (sequence similarity $97.3 \%$; Nielsen et al., 1995), followed by the type strains of Bacillus cellulosilyticus (96.2\%; Nogi et al., 2005), Bacillus clarkii (96.1\%; Nielsen et al., 1995) and Bacillus polygoni (96.0\%; Aino et al., 2008). Sequence similarities between strain JSM $071004^{\mathrm{T}}$ and other Bacillus species were below $96.0 \%$. In the phylogenetic tree, the novel isolate formed a distinct subline with the type strain of B. agaradhaerens (three methods; Fig. 1). To establish 


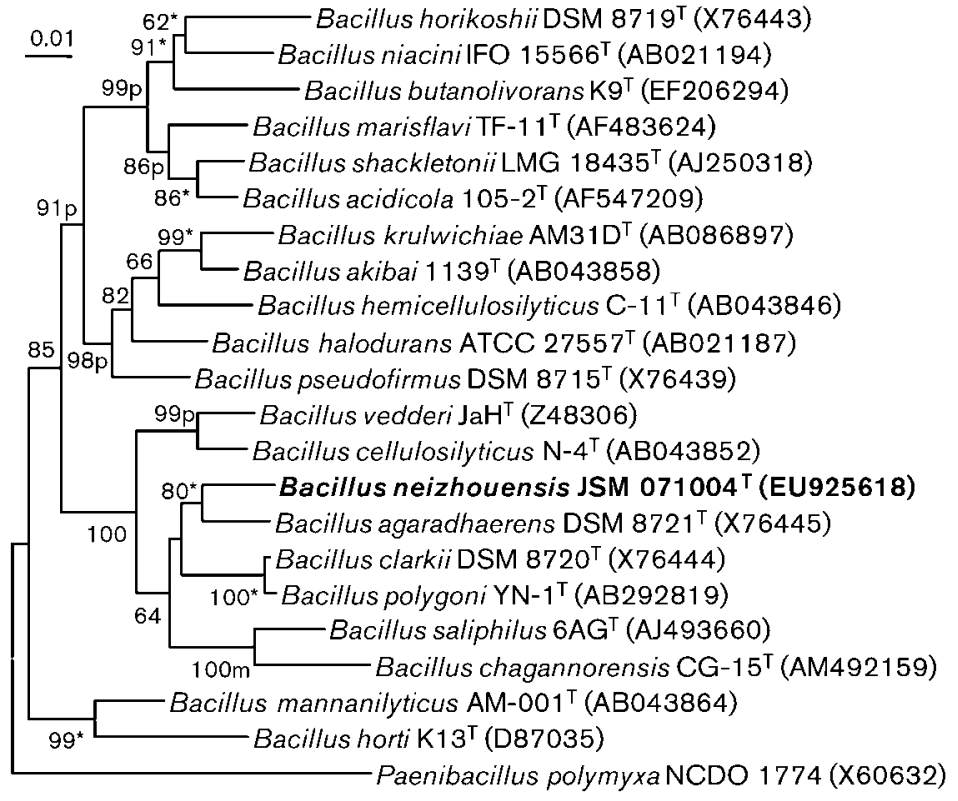

Fig. 1. Phylogenetic tree showing the positions of strain JSM $071004^{\top}$ and related taxa, based on 16S rRNA gene sequence analysis and reconstructed using the neighbour-joining method. ' $m$ ' or ' $p$ ' labels indicate branches that were also found with the maximum-likelihood (Felsenstein, 1981) or parsimony (Kluge \& Farris 1969) algorithms, respectively; asterisks indicate branches that were recovered with all three methods. Numbers at nodes indicate bootstrap values $(>50 \%)$ based on neighbour-joining analysis of 1000 resampled datasets. Bar, 1 substitution per 100 nucleotides. the precise taxonomic position of strain JSM $071004^{\mathrm{T}}$, DNA-DNA hybridizations were performed between the novel isolate and $B$. agaradhaerens DSM $8721^{\mathrm{T}}$, which revealed the level of DNA-DNA relatedness between them to be $13.4 \%$, far below the threshold value of $70 \%$ recommended by Wayne et al. (1987) for assigning strains to the same species. It is therefore evident, based on the results of phylogenetic analysis and DNA-DNA hybridization, that strain JSM $071004^{\mathrm{T}}$ represents a previously unknown species of the genus Bacillus (Wayne et al., 1987; Stackebrandt \& Goebel, 1994).

Amino acids of whole-cell hydrolysates were analysed as described by Hasegawa et al. (1983). Isoprenoid quinones were analysed by HPLC as described by Groth et al. (1996). Polar lipids were extracted according to the method of Minnikin et al. (1979) and were identified by twodimensional TLC and spraying with appropriate detection reagents (Collins \& Jones, 1980). Fatty acids were determined for the new isolate as well as for the reference strain B. agaradhaerens DSM $8721^{\mathrm{T}}$ as described by Sasser (1990) using the Microbial Identification System (MIDI; Microbial ID) with cells grown in $\mathrm{MB}$ ( $\mathrm{pH}$ 8.5) in flasks on a rotary shaker at 200 r.p.m. at $25{ }^{\circ} \mathrm{C}$ for 3 days. Chemotaxonomic data for strain JSM $071004^{\mathrm{T}}$ were consistent with its assignment to the genus Bacillus. The strain possessed a cell-wall type based on meso-diaminopimelic acid and contained MK-7 (99.6\%) as the predominant menaquinone, with MK-6 (0.4\%) present in trace amounts. The polar lipids of this strain consisted of diphosphatidylglycerol, phosphatidylglycerol and phosphatidylethanolamine. The fatty acid profile of strain JSM $071004^{\mathrm{T}}$ was similar to that of the type strain of $B$. agaradhaerens (Table 2). The major fatty acids of strain JSM $071004^{\mathrm{T}}$ were anteiso- $\mathrm{C}_{15: 0}(50.4 \%)$ and iso- $\mathrm{C}_{15: 0}$ $(12.1 \%)$.
The results of phylogenetic analysis and morphological and chemotaxonomic studies supported the view that strain JSM $071004^{\mathrm{T}}$ should be assigned to the genus Bacillus. However, the comparatively low growth temperatures (4$30{ }^{\circ} \mathrm{C}$ ), as well as its inability to hydrolyse Tweens 40 and 60 , differentiated the new isolate markedly from phylogenetically related Bacillus species (Table 1). Strain JSM $071004^{\mathrm{T}}$ could also be clearly distinguished from its phylogenetically closest neighbour, B. agaradhaerens, by some other discriminative taxonomic markers, such as its oxidase activity, its ability to hydrolyse gelatin and to grow at $\mathrm{pH} 6.5$ (Table 1) and the low level of DNA-DNA relatedness between them. Overall, the results presented here allowed us to assign the novel isolate to a novel species, for which we propose the name Bacillus neizhouensis sp. nov.

\section{Description of Bacillus neizhouensis sp. nov.}

Bacillus neizhouensis (nei.zhou.en'sis. N.L. masc. adj. neizhouensis pertaining to Neizhou Bay, from which the sample that yielded the type strain was collected).

Cells are Gram-stain-positive, non-motile, catalase- and oxidase-positive, aerobic, straight rods, approximately 0.5$0.6 \mu \mathrm{m}$ wide and $3.0-5.0 \mu \mathrm{m}$ long, occurring singly, as pairs or as short chains, producing ellipsoidal endospores that lie in subterminal swollen sporangia. Colonies are pale-yellow pigmented, low convex and translucent with circular/slightly irregular margins, $1-2 \mathrm{~mm}$ in diameter after incubation for $3-5$ days at $25{ }^{\circ} \mathrm{C}$ on marine agar 2216 (Difco). Slightly halophilic and facultatively alkaliphilic; growth occurs with $0.5-10 \%(\mathrm{w} / \mathrm{v})$ total salts (optimum 2$4 \%$ ) and at $\mathrm{pH}$ 6.5-10.0 (optimum $\mathrm{pH}$ 8.5). Growth occurs at $4-30{ }^{\circ} \mathrm{C}$, with an optimum of $25{ }^{\circ} \mathrm{C}$. Nitrate is reduced but nitrite is not. Negative for tests of methyl red, 
Table 2. Fatty acid composition of strain JSM $071004^{\top}$ and Bacillus agaradhaerens DSM $8721^{\top}$

Data are percentages of the total fatty acids, those representing $<1.0 \%$ in both strains being omitted. -, Not detected.

\begin{tabular}{|c|c|c|}
\hline Fatty acid & $\begin{array}{l}\text { B. neizhouensis } \\
\text { JSM } 071004^{\mathrm{T}}\end{array}$ & $\begin{array}{l}\text { B. agaradhaerens } \\
\text { DSM } 8721^{\mathrm{T}}\end{array}$ \\
\hline iso- $\mathrm{C}_{14: 0}$ & 5.1 & 1.0 \\
\hline iso- $\mathrm{C}_{15: 0}$ & 12.1 & 18.5 \\
\hline anteiso- $\mathrm{C}_{15: 0}$ & 50.4 & 45.6 \\
\hline iso- $\mathrm{C}_{16: 0}$ & 3.5 & 3.0 \\
\hline $\mathrm{C}_{16: 1} \omega 7 c$ alcohol & 7.4 & 3.4 \\
\hline $\mathrm{C}_{16: 1} \omega 11 c$ & 5.8 & 1.5 \\
\hline $\mathrm{C}_{16: 0}$ & - & 3.5 \\
\hline iso- $\mathrm{C}_{17: 0}$ & 4.0 & 3.8 \\
\hline anteiso- $\mathrm{C}_{17: 0}$ & 6.1 & 9.5 \\
\hline anteiso- $\mathrm{C}_{17: 1} \omega 10 c$ & 2.8 & 5.5 \\
\hline $\mathrm{C}_{18: 1} \omega 9 c$ & - & 2.7 \\
\hline
\end{tabular}

Voges-Proskauer, $\mathrm{H}_{2} \mathrm{~S}$ and indole production. Aesculin and gelatin are hydrolysed, but casein, cellulose, DNA, starch, Tweens 20, 40, 60 and 80 and urea are not. Acids are produced from D-fructose, D-glucose, maltose, sucrose and trehalose, but not from adonitol, L-arabinose, cellobiose, dulcitol, D-galactose, glycerol, myo-inositol, lactose, Dmannitol, D-mannose, melezitose, melibiose, raffinose, L-rhamnose, D-ribose, D-salicin, starch, D-sorbitol or Dxylose. The following compounds are utilized as sole sources of carbon and energy or sole sources of carbon, nitrogen and energy: D-glucose, maltose, trehalose and L-leucine; the following substances are not utilized: Larabinose, cellobiose, dextrin, D-fructose, D-galactose, D-lactose, D-mannose, melezitose, melibiose, raffinose, Lrhamnose, D-ribose, D-salicin, sucrose, D-xylose, adonitol, D-arabitol, glycerol, myo-inositol, D-mannitol, D-sorbitol, acetate, butyrate, citrate, gluconate, propionate, succinate, L-alanine, L-arginine, L-asparagine, L-glutamic acid, glycine, L-histidine, hydroxy-L-proline, L-isoleucine, L-methionine, L-proline, L-serine and L-valine. Constitutive enzymes expressed are alkaline phosphatase, $\beta$-glucosidase, $\beta$ glucuronidase, leucine arylamidase and naphthol-AS-BIphosphohydrolase; acid phosphatase, $\alpha$-chymotrypsin, cystine arylamidase, $\alpha$-fucosidase, $\alpha$-galactosidase, $\beta$-galactosidase, $N$-acetyl- $\beta$-glucosaminidase, $\alpha$-glucosidase, esterase (C4), esterase lipase (C8), lipase (C14), $\alpha$-mannosidase, trypsin and valine arylamidase are not observed. Susceptible to ( $\mu \mathrm{g}$ per disc) ampicillin (30), carbenicillin (30), chloramphenicol (30), gentamicin (10), kanamycin (30), nitrofurantoin (30), novobiocin (30), polymixin B (30), rifampicin (5) and streptomycin (10), but not to lincomycin (2), nalidixic acid (20), tetracycline (30) or tobramycin (10). meso-Diaminopimelic acid is present in the cell-wall peptidoglycan as the diagnostic diamino acid. Possesses MK-7 as the predominant menaquinone and diphosphatidylglycerol, phosphatidylglycerol and phosphatidylethanolamine as polar lipids. The major fatty acids are anteiso- $\mathrm{C}_{15: 0}$ and iso- $\mathrm{C}_{15: 0}$. The DNA G $+\mathrm{C}$ content of the type strain is $39.8 \mathrm{~mol} \%$ (HPLC method).

The type strain, JSM $071004^{\mathrm{T}}\left(=\mathrm{CCTCC}\right.$ AB $207161^{\mathrm{T}}$ $=$ DSM $19794^{\mathrm{T}}=$ KCTC $13187^{\mathrm{T}}$ ), was isolated from homogenates of a sea anemone collected from Neizhou Bay in the South China Sea.

\section{Acknowledgements}

This work was supported by grants from the National Natural Science Foundation of China (NSFC) (30970007, 30860013), Jishou University (jsdxkyzz200811, JSS2009Z01), the Ministry of Science and Technology, PR China (2010CB833800) and the Yunnan Provincial Sciences and Technology Department (2005PY01-1, 2006C0006M, 2006C0004M). W.-J. L. was supported by the Program for New Century Excellent Talents in University. We are grateful to Mr Yun Chen and $\mathrm{Mr}$ Ke Huang for their excellent technical assistance.

\section{References}

Aino, K., Hirota, K., Matsuno, T., Morita, N., Nodasaka, Y., Fujiwara, T., Matsuyama, H., Yoshimune, K. \& Yumoto, I. (2008). Bacillus polygoni sp. nov., a moderately halophilic, non-motile obligate alkaliphile isolated from indigo balls. Int J Syst Evol Microbiol 58, 120-124.

Arahal, D. R. \& Ventosa, A. (2002). Moderately halophilic and halotolerant species of Bacillus and related genera. In Applications and Systematics of Bacillus and Relatives, pp. 83-99. Edited by R. C. W. Berkeley, M. Heyndrickx, N. Logan \& P. De Vos. Oxford: Blackwell.

Ash, C., Farrow, J. A. E., Wallbanks, S. \& Collins, M. D. (1991). Phylogenetic heterogeneity of the genus Bacillus as revealed by comparative analysis of small-subunit ribosomal-RNA sequences. Lett Appl Microbiol 13, 202-206.

Atlas, R. M. (1993). Handbook of Microbiological Media. Edited by L. C. Parks. Boca Raton, FL: CRC Press.

Carrasco, I. J., Márquez, M. C., Xue, Y., Ma, Y., Cowan, D. A., Jones, B. E., Grant, W. D. \& Ventosa, A. (2007). Bacillus chagannorensis sp. nov., a moderate halophile from a soda lake in Inner Mongolia, China. Int J Syst Evol Microbiol 57, 2084-2088.

Chen, Y.-G., Cui, X.-L., Pukall, R., Li, H.-M., Yang, Y.-L., Xu, L.-H., Wen, M.-L., Peng, Q. \& Jiang, C.-L. (2007). Salinicoccus kunmingensis sp. nov., a moderately halophilic bacterium isolated from a salt mine in Yunnan, south-west China. Int J Syst Evol Microbiol 57, 23272332.

Chen, Y.-G., Zhang, Y.-Q., Shi, J.-X., Xiao, H.-D., Tang, S.-K., Liu, Z.-X., Huang, K., Cui, X.-L. \& Li, W.-J. (2009a). Jeotgalicoccus marinus sp. nov., a marine bacterium isolated from a sea urchin. Int J Syst Evol Microbiol 59, 1625-1629.

Chen, Y.-G., Zhang, Y.-Q., Xiao, H.-D., Liu, Z.-X., Yi, L.-B., Shi, J.-X., Zhi, X.-Y., Cui, X.-L. \& Li, W.-J. (2009b). Pontibacillus halophilus sp. nov., a moderately halophilic bacterium isolated from a sea urchin. Int J Syst Evol Microbiol 59, 1635-1639.

Chun, J., Lee, J.-H., Jung, Y., Kim, M., Kim, S., Kim, B. K. \& Lim, Y. W. (2007). EzTaxon: a web-based tool for the identification of prokaryotes based on $16 \mathrm{~S}$ ribosomal RNA gene sequences. Int J Syst Evol Microbiol 57, 2259-2261.

Collins, M. D. \& Jones, D. (1980). Lipids in the classification and identification of coryneform bacteria containing peptidoglycans based on 2,4-diaminobutyric acid. J Appl Bacteriol 48, 459-470. 
Cowan, S. T. \& Steel, K. J. (1965). Manual for the Identification of Medical Bacteria. London: Cambridge University Press.

Cui, X.-L., Mao, P.-H., Zeng, M., Li, W.-J., Zhang, L.-P., Xu, L.-H. \& Jiang, C.-L. (2001). Streptomonospora salina gen. nov., sp. nov., a new member of the family Nocardiopsaceae. Int J Syst Evol Microbiol 51, 357-363.

Ezaki, T., Hashimoto, Y. \& Yabuuchi, E. (1989). Fluorometric deoxyribonucleic acid-deoxyribonucleic acid hybridization in microdilution wells as an alternative to membrane filter hybridization in which radioisotopes are used to determine genetic relatedness among bacterial strains. Int J Syst Bacteriol 39, 224-229.

Felsenstein, J. (1981). Evolutionary trees from DNA sequences: a maximum likelihood approach. J Mol Evol 17, 368-376.

Felsenstein, J. (1985). Confidence limits on phylogenies: an approach using the bootstrap. Evolution 39, 783-791.

Felsenstein, J. (2002). PHYLIP (phylogeny inference package), version 3.6a. Distributed by the author. Department of Genome Sciences, University of Washington, Seattle, USA.

Gregersen, T. (1978). Rapid method for distinction of Gram-negative from Gram-positive bacteria. Eur J Appl Microbiol Biotechnol 5, 123127.

Groth, I., Schumann, P., Weiss, N., Martin, K. \& Rainey, F. A. (1996). Agrococcus jenensis gen. nov., sp. nov., a new genus of actinomycetes with diaminobutyric acid in the cell wall. Int J Syst Bacteriol 46, 234239.

Hasegawa, T., Takizawa, M. \& Tanida, S. (1983). A rapid analysis for chemical grouping of aerobic actinomycetes. J Gen Appl Microbiol 29, 319-322.

Hopwood, D. A., Bibb, M. J., Chater, K. F., Kieser, T., Bruton, C. J., Kieser, H. M., Lydiate, D. J., Smith, C. P. \& Ward, J. M. (1985). Preparation of chromosomal, plasmid and phage DNA. In Genetic Manipulation of Streptomyces: a Laboratory Manual, pp. 79-80. Norwich, UK: John Innes Foundation.

Horikoshi, K. (1999). Alkaliphiles: some applications of their products for biotechnology. Microbiol Mol Biol Rev 63, 735-750.

Kimura, M. (1980). A simple method for estimating evolutionary rates of base substitutions through comparative studies of nucleotide sequences. J Mol Evol 16, 111-120.

Kluge, A. G. \& Farris, F. S. (1969). Quantitative phyletics and the evolution of anurans. Syst Zool 18, 1-32.

Krulwich, T. A., Hicks, D. B., Swartz, T. H. \& Ito, M. (2007). Bioenergetic adaptations that support alkaliphily. In Physiology and Biochemistry of Extremophiles, pp. 311-329. Edited by C. Gerday \& N. Glansdorff. Washington, DC: American Society for Microbiology.

Lim, J.-M., Jeon, C. O. \& Kim, C.-J. (2006a). Bacillus taeanensis sp. nov., a halophilic Gram-positive bacterium from a solar saltern in Korea. Int J Syst Evol Microbiol 56, 2903-2908.

Lim, J.-M., Jeon, C. O., Lee, S.-M., Xu, L.-H., Jiang, C.-L. \& Kim, C.-J. (2006b). Bacillus salarius sp. nov., a halophilic, spore-forming bacterium isolated from a salt lake in China. Int J Syst Evol Microbiol 56, 373-377.

Margesin, R. \& Schinner, F. (2001). Potential of halotolerant and halophilic microorganisms for biotechnology. Extremophiles 5, 73-83.

Mesbah, M., Premachandran, U. \& Whitman, W. B. (1989). Precise measurement of the $\mathrm{G}+\mathrm{C}$ content of deoxyribonucleic acid by highperformance liquid chromatography. Int J Syst Bacteriol 39, 159-167.
Minnikin, D. E., Collins, M. D. \& Goodfellow, M. (1979). Fatty acid and polar lipid composition in the classification of Cellulomonas, Oerskovia and related taxa. J Appl Bacteriol 47, 87-95.

Nielsen, P., Rainey, F. A., Outtrup, H., Priest, F. G. \& Fritze, D. (1994). Comparative $16 \mathrm{~S}$ rDNA sequence analysis of some alkaliphilic bacilli and the establishment of a sixth rRNA group within the genus Bacillus. FEMS Microbiol Lett 117, 61-66.

Nielsen, P., Fritze, D. \& Priest, F. G. (1995). Phenetic diversity of alkaliphilic Bacillus strains: proposal for nine new species. Microbiology 141, 1745-1761.

Nogi, Y., Takami, H. \& Horikoshi, K. (2005). Characterization of alkaliphilic Bacillus strains used in industry: proposal of five novel species. Int J Syst Evol Microbiol 55, 2307-2315.

Romano, I., Lama, L., Nicolaus, B., Gambacorta, A. \& Giordano, A. (2005). Bacillus saliphilus sp. nov., isolated from a mineral pool in Campania, Italy. Int J Syst Evol Microbiol 55, 159-163.

Saitou, N. \& Nei, M. (1987). The neighbor-joining method: a new method for reconstructing phylogenetic trees. Mol Biol Evol 4, 406425.

Sasser, M. (1990). Identification of bacteria by gas chromatography of cellular fatty acids. MIDI Technical Note 101. Newark, DE: MIDI Inc.

Smibert, R. M. \& Krieg, N. R. (1994). Phenotypic characterization. In Methods for General and Molecular Bacteriology, pp. 607-654. Edited by P. Gerhardt, R. G. E. Murray, W. A. Wood \& N. R. Krieg. Washington, DC: American Society for Microbiology.

Stackebrandt, E. \& Goebel, B. M. (1994). Taxonomic note: a place for DNA-DNA reassociation and $16 \mathrm{~S}$ rRNA sequence analysis in the present species definition in bacteriology. Int J Syst Bacteriol 44, 846849.

Tamura, K., Dudley, J., Nei, M. \& Kumar, S. (2007). MEGA4: molecular evolutionary genetic analysis (MEGA) software version 4.0. Mol Biol Evol 24, 1596-1599.

Thompson, J. D., Gibson, T. J., Plewniak, F., Jeanmougin, F. \& Higgins, D. G. (1997). The CLUSTAL_X windows interface: flexible strategies for multiple sequence alignment aided by quality analysis tools. Nucleic Acids Res 25, 4876-4882.

Ventosa, A., Quesada, E., Rodriguez-Valera, F., Ruiz-Berraquero, F. \& Ramos-Cormenzana, A. (1982). Numerical taxonomy of moderately halophilic Gram-negative rods. J Gen Microbiol 128, 1959-1968.

Wayne, L. G., Brenner, D. J., Colwell, R. R., Grimont, P. A. D., Kandler, O., Krichevsky, M. I., Moore, L. H., Moore, W. E. C., Murray, R. G. E. \& other authors (1987). International Committee on Systematic Bacteriology. Report of the ad hoc committee on reconciliation of approaches to bacterial systematics. Int J Syst Bacteriol 37, 463-464.

Xiao, H.-D., Chen, Y.-G., Liu, Z.-X., Huang, K., Li, W.-J., Cui, X.-L., Zhang, L. \& Yi, L.-B. (2009). Phylogenetic diversity of cultivable bacteria associated with a sea anemone from coast of the Naozhou Island in Zhanjiang, China. Wei Sheng Wu Xue Bao 49, 246-250 (in Chinese with English abstract).

Yoon, J.-H., Kim, I.-G., Kang, K. H., Oh, T.-K. \& Park, Y.-H. (2004). Bacillus hwajinpoensis sp. nov. and an unnamed Bacillus genomospecies, novel members of Bacillus rRNA group 6 isolated from sea water of the East Sea and the Yellow Sea in Korea. Int J Syst Evol Microbiol 54, 803-808.

Yumoto, I. (2007). Environmental and taxonomic biodiversities of Gram-positive alkaliphiles. In Physiology and Biochemistry of Extremophiles, pp. 295-310. Edited by C. Gerday \& N. Glansdorff. Washington, DC: American Society for Microbiology. 